logos_i_ethos_2021_(57), s. 261-292

DOI: http://dx.doi.org/10.15633/lie.4041

Rev. Miłosz Hołda

https://orcid.org/0000-0003-0649-2168

The Pontifical University of John Paul II in Krakow

\title{
Tischner's dispute with Kołakowski over grace and freedom
}

\section{Introduction}

The dispute over the problem concerned with the relationship between grace and freedom engaged in by Saint Augustine and Pelagius is not merely an interesting element in the history of human thought. This controversy, which had been generated centuries ago, has been many a time revived, and still continues, undergoing new stages. One of these, which is addressed in the present text, is the stage of Józef Tischner's dispute with Leszek Kołakowski. Tischner was earnest about Kołakowski's in-
Rev. Miłosz Hołda, a doctor of philosophy with a habilitation degree, an assistant professor at the Department of Metaphysics and Philosophy of Man, the Faculty of Philosophy at the Pontifical University of John Paul II in Cracow, a lecturer at the John Paul II Catholic University of Lublin. He has authored three books and several dozen research papers, and was awarded the prize of the President of the Council of Ministers for the rewarded doctoral dissertation in 2013. His most recent publication is Źródło i noc. Wprowadzenie do współczesnego absconditeizmu [The Spring and the Night. An Introduction to Contemporary Absconditheism] (Kraków 2020). He specializes in natural theology, philosophy of man, and epistemology. He is a member of the Internationale-Ferdinand-Ebner-Gesellschaft.

terpretation of one of the stages of this controversy, i.e. the 17 th-century dispute between Jansenists, Pascal being the foremost among them, and Jesuit theologians. However, he interpreted Kołakowski's view as a voice in the discussion - which transcended a specific historical context - of the problematic relationship between grace and freedom. It is noteworthy that the dispute was "uni-directional:" Tischner discussed 
and criticized Kołakowski's views. That is why it is advisable to speak of Tischner's dispute with Kołakowski, and not of dispute between Tischner and Kołakowski. This, however, is no impediment to viewing their texts as presentation of two relevant positions that can and should be evaluated.

In the present text I will outline the origin and the crucial elements in the history of the controversy over grace and freedom. It is necessary to outline the history in order to set the backdrop for the controversy stage in question. Both Kołakowski and Tischner refer to the views held by the participants in the earlier stages of the controversy, and propose solutions that are comprehensible only after one has understood the solutions put forth earlier. Outlining the backdrop will also make it possible to show the misunderstandings and over-interpretations that appear particularly in Kołakowski's texts that treat of these issues. Then, I will present the views held by the thinkers in question: the reconstruction of the 17th-century dispute between Jansenists and Molinists by Kołakowski, who suggests that the solution embraced in the dispute by the Catholic Church was semi-Pelagianism, as well as Tischner's criticism of Kołakowski's views and the solution proposed by the former, which is in the spirit of Saint Augustine's (appropriately interpreted) teaching. To conclude, I will try to resolve this dispute, showing how the positions taken by Kołakowski and Tischner might be reconciled, and point to the ramifications of this dispute for fields of thought other than theology.

The controversy over the relationship between grace and freedom is not merely a narrow controversy over one of many elements in the heritage of Christian theology. Even though it is rooted in theology, it translates into many crucial issues concerned with both thinking about education and thinking about politics. That is why a philosopher too can find this controversy interesting. ${ }^{1}$ It is necessary to understand the

1 As a matter of fact, Tischner implies that the experience of grace does not lie in theological research only. Theology addresses only one, "supernatural" aspect of this concept. However, grace has an experiential aspect too, and that is why "the experience of grace can and even must become a philosophical subject" (J. Tischner, Zarys filozofii człowieka dla duszpasterzy i artystów [An 
theological concepts at play as well as the entire theological "background" to the controversy so that we can engage in discussion of the subjects belonging in the philosophy of education and the philosophy of politics.

Of the relevance of this controversy for the contemporary times, and in reference to Kołakowski's book God Owes Us Nothing, ${ }^{2}$ Tischner writes as follows: "The book is targeted at a specific reader. He is a contemporary man who has experienced totalitarianism, and carries in his soul Pascal's conflict between trust in man and unbelief in man." And he asks: "How is it then: to believe or not to believe in man?"3 Tischner also notes the following: "In Kołakowski's opinion the Jansenist-Jesuit conflict in some measure still holds. After all that we have experienced in this century do we still have grounds to trust in man? The knowledge we have acquired of man gives rise to despair. However, he who has lapsed into despair because of man, and has placed his trust in God, should know: God owes us nothing. Which side should we take?"4 In the present text we will pursue this question. We will, however, supplement it with another question. It reads: who should we side with - Kołakowski or Tischner? The answer to this question is much more important than it might seem at first glance.

\section{The origin of the controversy}

Saint Augustine's dispute with Pelagius' views marks the beginning of the controversy, one of the latest stages of which is the focus of our interest. ${ }^{5}$ The problem with this dispute is that we do not really know the

Outline of the Philosophy of Man for Priests and Artists], in: J. Tischner, Myślenie w żywiole piękna [Thinking in the Element of Beauty], Kraków 2013, p. 291).

2 L. Kołakowski, Bóg nam nic nie jest dłużny. Krótka uwaga o religii Pascala i o duchu janseni$z m u$ [God Owes Us Nothing: A Brief Remark on Pascal's Religion and on the Spirit of Jansenism], tłum. I. Kania, Kraków 1994.

3 J. Tischner, Szukając mistrzów naszej wiary [In Search of the Masters of Our Faith], in: J. Tischner, Ksiądz na manowcacach [A Priest in the Wilderness], Kraków 1999, p. 236.

4 J. Tischner, Szukając mistrzów naszej wiary, op. cit., pp. 236-237.

5 The best study of the history of the controversy over grace and freedom, which Tischner directly refers to, is: D. Oko, Łaska i wolność. Łaska w Biblii, nauczaniu Kościoła i teologii wspótczesnej 
true views held by Pelagius. It is also unclear whether Augustine's criticism was well-directed with regard to what Pelagius actually preached. ${ }^{6}$ However, Tischner believes that Pelagianism and Augustinianism can be viewed as paradigms of thinking about grace within the Christian tradition. Treating Pelagius' views precisely like this, Tischner claims that Pelagius' true intention was to oppose cheap, "effortless" Christianity. Pelagius strove after a spiritual revival predicated on moral rigorism. As a soul-shepherd and preacher he above all aimed to educate his followers. In the opinion of Pelagius, who was actuated by the Greek idea of paideia - man's self-improvement - man is supposed to strive after perfection, and philosophy and religion are there to show him the road and the destination.

According to Tischner, Pelagius believed that man has capacity for sinlessness and attaining salvation, because he was created in the image of God. The ability to develop and reach the goal, i.e. salvation, is a peculiar dynamism that man is endowed with. The grace brought by Jesus Christ is not necessary for salvation, but acts only as instruction. Sin did not frustrate the possibility of salvation originally offered to man, and it was only a bad example that stood in the way of attaining salvation. As Tischner emphasizes, the important thing is that Pelagius' views opposed Manichaeism. Pelagius believed that Manichaeism plunges man into fatalism, turning him into a passive observer of evil in the world. In the concept proposed by Pelagius man is not condemned to passive observation of evil, but is in a position to become committed on the side of good.

As he writes about Pelagius, G. Müller observes that he "was in fact more of a religious zealot than a profound theological thinker."

[Grace and Freedom. Grace in the Bible, the Catholic Church Teachings and Contemporary Theology], Kraków 1997.

6 Tischner explains: "Irrespective of what Pelagius and Augustine thought of grace, the paradigm is important, just like for a river important are both its banks. If there were no paradigm like this, then we would have to think it up" (J. Tischner, Podgladanie Pana Boga [Stealthily Watching God], in: J. Tischner, Ksiądz na manowcach, op. cit., p. 255).

7 J. Tischner, Spór o istnienie człowieka [A Controversy over the Existence of Man], Kraków 2011, pp. 162-164. 
In Müller's opinion, contrary to what Augustine and the theological tradition ascribed to him, he did not reject grace. He was aware that man is saved through grace. Importantly, he construed it as a natural capacity to do good. Even if he regarded Jesus as a model to be emulated, he did not understand the word "model" in today's moralistic sense. In Pelagius' opinion - adds Müller - faith is supported by grace. The support in question, however, is a type of support limited to "facilitating knowledge and easier performance of moral good."

Pelagius' thought had clear implications in the sphere of views on education. In his opinion Christianity is a religion for adults. For a child, who cannot be blamed for anything and so does not need to be absolved of its sins, baptism is merely an initiation into the reality of the Kingdom of God. Original sin did not change the condition of human nature. Biblical Adam did not mar the nature by sin, but only set a bad example for mankind. ${ }^{9}$ Pelagius emphasized the significance of the act of creation. Grace, which was bestowed upon man in this act was neither cancelled nor obliterated as a result of original sin; nature was not destroyed, but only exposed to a bad example, the effect of which can and needs to be shaken off with the assistance of Christ. One might conclude that the essence of Pelagianism is the belief that as regards his salvation, man can achieve a lot, if not everything. The guarantor of this "power" is "creation" understood as endowment of man with capacity for action. The one who ultimately grants salvation is, therefore, God. However, salvation is connected rather with the act of creation than the person and redemptive mission of Jesus Christ.

These views were opposed by Saint Augustine, who found them excessively optimistic. ${ }^{10}$ He stressed that grace, contrary to what Pelagians

8 G. Müller, Dogmatyka katolicka [Catholic Dogmatics], tłum. W Szymona, Kraków 2015, p. 797.

9 See V. Grossi, L. Ladaria, P. Lécrivain, B. Sesboüé, Historia dogmatów [History of Dogmas], t. 2: Człowiek i jego zbawienie [Man and His Salvation], tłum. P. Rak, Kraków 2001, p. 252.

10 This polemical feature of Augustine's views is extremely important. This is pointed out by A. Kijewska, who writes: "The Augustinian doctrine of grace, prevalent particularly in his late works, needs to be considered in the context of the entirety of his thought, which was formed by doctrinal 
believed, is not merely a capability not to sin received from God in conjunction with free will. Neither is grace merely a good example. In Augustine's opinion grace is aid indispensable in not committing sins. Augustine believed that as a result of original sin human nature was harmed, destroyed, tormented and forfeited. This view translates into an image of the process of education that is completely different from the one arising from Pelagianism. Augustine believes that education alone is not enough to put nature right. God's constant, supernatural aid is necessary.

However, it is noteworthy that Augustine does not oppose grace to freedom. In one of his major writings on this issue he cites Saint Paul's words: "yet not I, but the grace of God [...] with me."11 He holds that "we are certainly the subjects of our deeds, but it is God who very effectively reinforces our will and thus is their cause." ${ }^{12}$ Grace neither invalidates nor downgrades human freedom. Man achieves and realizes the capabilities of one's own freedom through grace, and not the other way round. Augustine writes: "Because the human will does not attain grace by freedom, but rather attains freedom by grace, and a delightful constancy, and an insuperable fortitude that it may persevere." ${ }^{\text {"13 }}$ According to Augustine, Adam was created in God's grace. That is why his condition was different from ours in three respects: he could not die, he did not know of the struggle of the flesh against the spirit, he had capacity for sinlessness. Still, he committed a sin and in consequence all mankind followed him. Hence, no one is born in the condition of innocent Adam, but in the condition of a being afflicted by sin. Deliverance from this sinful heritage takes place through Christ's grace. The grace

polemics with Manichaeans, Academics, Platonists, Pelagians and Donatists. His last works, which served as solutions to specific problems that were referred to him, frequently led to various overinterpretations" (A. Kijewska, Augustyńskie dziedzictwo [The Augustinian Heritage], in: Przewodnik po filozofi średniowiecznej. Odśs. Augustyna do Joachima z Fiore [A Companion to Medieval Philosophy. From Saint Augustine to Joachim of Fiore], red. A. Kijewska, Kraków 2012, p. 36).

11 See św. Augustyn, Łaska a wolna wola [On Grace and Free Will], in: Augustyn, Łaska, wiara, przeznaczenie [Grace, Faith, Destiny], tłum. E. Eborowicz, Poznań-Warszawa-Lublin 1970, p. 118.

12 Św. Augustyn, Łaska a wolna wola, op. cit., p. 134.

13 Św. Augustyn, Nagana i łaska [On Rebuke and Grace], in: Augustyn, Łaska, wiara, przeznaczenie, op. cit., p. 180. 
granted to Adam was indispensable aid - without it Adam would not be able to persevere in the good in which he had been created. Augustine called grace thus construed: adiutorium sine qua non. The grace brought by Christ to people suffering from the effects of original sin does not only provide the power of perseverance, but perseverance itself - in other words, aid thanks to which we can persevere. Augustine called this type of grace adiutorium quo. ${ }^{14}$ According to Augustine, grace is not only aid, but a condition for all possible good works that are performed by human subjects. Therefore, Augustine appears to take a much more pessimistic position than the one adopted by Pelagians with regard to human nature and its condition in the wake of original sin. The opposite of this pessimism is absolute trust placed in Divine grace.

\section{Semi-Pelagianism ${ }^{15}$}

In 418 , the Council of Carthage condemned Pelagianism. ${ }^{16}$ It confirmed the necessity of Divine grace not only for remission of sins, but also as aid allowing man not to sin any more. In light of the synod pronouncements, the role of grace consists in granting power, and not just setting a good example for man. In response to the crisis of Pelagianism, which

14 V. Grossi, L. Ladaria, P. Lécrivain, B. Sesboüé, Historia dogmatów [History of Dogmas], op. cit., p. 257.

15 A neat definition of this position is presented by Müller: "Since the 16th century semi-Pelagianism has been a universally accepted term to denote the reaction which emerged in Africa and Southern Gaul to the Augustinian teaching on grace as absolutely necessary for every worthy deed" (G. Müller, Dogmatyka katolicka, op. cit., p. 798).

16 The following are some crucial pronouncements by the council: "[...] whoever should say that the grace of God, by which a man is justified through Jesus Christ our Lord, avails only for the remission of past sins, and not for assistance against committing sins in the future, let him be anathema" (Canon 3); "[...] whoever shall say that the same grace of God through Jesus Christ our Lord helps us only in not sinning by revealing to us and opening to our understanding the commandments, so that we may know what to seek, what we ought to avoid, and also that we should love to do so, but that through it we are not helped so that we are able to do what we know we should do, let him be anathema" (Canon 4) (as cited in: Breviarium fidei. Wybór doktrynalnych wypowiedzi Kościoła [Breviarium fidei. A Selection of the Church's Doctrinal Pronouncements], opracowali S. Głowa i I. Bieda, Poznań 1997, p. 286). 
was caused by the condemnations issued by the Council of Carthage, or perhaps even more firmly as an expression of disagreement with some of Augustine's statements on grace, a movement called semi-Pelagianism emerged. The originators of this movement were Provençal monks, students of John Cassian (one of them being Prosper of Aquitaine). Semi-Pelagians repudiated Pelagius' extreme propositions. They accepted the Augustinian proposition whereby grace is necessary. However, they believed that grace follows a determination of will. In their opinion will precedes grace. Metaphorically, this could be presented thus: human seeks a doctor, because man realizes that he can do nothing on his own.

The views held by the semi-Pelagians were rooted in their way of life. Most of them were devout monks. Prayers and mortifications, which were critical elements in their lives and practice of faith, were considered to be acts preparatory to receiving grace. They believed that he who prayed a lot and engaged in practices of mortification was sure to receive the grace of faith. Their views could be summed up thus: "man begins, but God ends." Semi-Pelagians also took the view that man can persevere in faith thanks to his own will.

The Council of Orange in 529 took issue with their views ${ }^{17}$. The Synodal fathers stressed that the beginning of faith does not result from purely human effort. Even if man embarks on the path of conversion and - to use a semi-Pelagian metaphor - begins looking for a doctor, this is happening, because grace is already at work in him. It is through grace alone that man begins asking for it. And so it is not the case that "man begins, but God ends." God is at work from the beginning as well.

17 In the Canons of the Council of Orange we can read, among other things: "If anyone says that the grace of God can be conferred as a result of human prayer, but that it is not grace itself which makes us pray to God, he contradicts the prophet Isaiah, or the Apostle who says the same thing, «I have been found by those who did not seek me; I have shown myself to those who did not ask for me.»" [Isaiah 65:1; Romans 10:20] (Canon 3); "If anyone says that not only the increase of faith but also its beginning and the very desire for faith, by which we believe in Him who justifies the ungodly and comes to the regeneration of holy baptism - if anyone says that this belongs to us by nature and not by a gift of grace, that is, by the inspiration of the Holy Spirit amending our will and turning it from unbelief to faith and from godlessness to godliness, it is proof that he is opposed to the teaching of the Apostles..." (Canon 5) (Breviarium fidei, op. cit., p. 298). 
Liberation is not a one-off act that takes place at the beginning, but it is continually granted to man in the process of sanctification.

Also, the Council of Orange was critical about some of the elements in Saint Augustine's doctrine. One of the repudiated convictions was that God grants grace to whomever he wills, but He does not grant it to everyone. Saint Augustine believed that the fact that only some are chosen for salvation is by no means unjust. Granting grace only to the elect is a consequence of God's transcendence we are too small to judge God on this, or to oppose Him. ${ }^{18}$ According to Saint Augustine God condemns no one. He just does not help some people, leaving them out there with the sins they have committed. This does not, however, mean that any one is forced to do evil. There is no way we can know the reasons why God does this. Saint Augustine believes that these reasons will be made clear to us in the life to come. The repudiation of the conviction that God grants grace to whomever he wills, but He does not grant it to everyone goes to prove that the Church did not accept Augustine's views unquestioningly. ${ }^{19}$ It followed his line of thought for good reasons.

18 Saint Augustine writes: "Here, if I am asked why God should not have given them perseverance to whom He gave that love by which they might live Christianly, I answer that I do not know. For I do not speak arrogantly, but with acknowledgement of my small measure, when I hear the apostle saying, "O man, who are you that repliest against God?» (Romans 9:20) and, «O the depth of the riches of the wisdom and knowledge of God! How unsearchable are His judgments, and His ways untraceable!» (Romans 11:33). So far, therefore, as He condescends to manifest His judgments to us, let us give thanks; but so far as He thinks fit to conceal them, let us not murmur against His counsel, but believe that this also is the most wholesome for us" (św. Augustyn, Nagana i łaska, op. cit., p. 180).

19 Louis Bouyer notes: "It is important, however, to remember here that the Church has never in any way confirmed Augustine's formulations and concepts concerned with predestination (primeval selection of some to be saved by God's sovereign decision, and abandonment of the so-called massa damnationis, condemned to damnation), or its concrete, historical and psychological effects" (L. Bouyer, Duch Święty Pocieszyciel [The Holy Spirit the Comforter], tłum. A. Liduchowska, Kraków 1998, p. 275). 


\section{Augustine's teaching on grace and freedom - its (over-) interpretations}

From the viewpoint of the contemporary studies of Saint Augustine's thought, his approach appears to be particularly adequate as regards resolution of the problem of two freedoms - of God and of man. Throughout the history of theology, one "side" only has often been chosen, the consequence being the narrowing of the horizon. Augustine was able to harmonize the essential elements that need to be taken into account, if one wants to develop a theology of grace and freedom that not only corresponds to the biblical data, but is also convincing.

In Augustine's thought the whole problem has a Christological grounding, and hence a historico-redemptive, and not purely abstract dimension. It is this feature that was to be lost in the history of the relationship between freedom and grace. Augustine is also wisely respectful of the Mystery. He claims that man cannot see through God's inscrutable plans. Even though Augustine misapplied this proposition to defend the thesis about the limited scope of grace, the proposition itself does not need to have such consequences.

For Augustine, grace is a relationship, and not a "thing" which God can give to man, or which God can withhold from him. Grace is not reifiable "mediation" that exists irrespective of anything else, but it is a manifestation of God's kindness to man - kindness that is personal. Hence, man's response must be personal as well. Augustine shows that God sustains man in free action, just like He sustains him in being. One can reject God's help, and oppose His guidance. One then loses "freedom" without losing "free will" - this distinction is of great importance for Augustine. In his opinion free will mediates on behalf of freedom. Exercising one's free will enables freedom to internalize God's gift over the course of time - the more freedom becomes reinforced in God, the less it is subject to the volatility of free will. One might say that for $\mathrm{Au}$ gustine freedom is not so much a possibility of making choices, as love of good - steady love that is guaranteed by having one's will oriented towards good, i.e. God. Grace assists man's free will, providing it with 
a concrete possibility of becoming freedom. The moment Adam committed a sin, he lost freedom, but did not lose his free will. Grace does not supplant free will, but enables it to exercise freedom again. These two factors are not to be found on the same plane, like "horses pulling the same wagon." In man's good action everything comes from grace, but at the same time everything comes from freedom. That is the way to resolve the conflict between the two forces, although it might seem to be irresolvable at first glance. ${ }^{20}$

On account of such a conception of grace and freedom, and the relationship between them, the conception of education changes as well. Now it is about providing orientation. Education exerts a real influence on man. However, it does not consist in conditioning. The role of an educator is to facilitate the release of freedom. At first good will is small and incapable (parva et invalida), but then it becomes great and capable of doing that which it desires (magna et robusta). Grace, which also becomes small or great, gets adjusted to this gradual release. The release of man does not take place in one moment, but takes time. ${ }^{21}$

Saint Augustine of Hippo's theology of grace and freedom is a result of his peculiar manner of approaching theological issues. G. Müller describes this approach as follows: "Augustine is a typical existential theologian who in his thinking does not employ abstract, speculative concepts of later theology, but he abides by the concrete, historical order of the early Christian biblical tradition. Hence, he does not know the abstract notion of human nature (natura pura), which in fact has never been realized, but analyzes man in specific modes of existence which according to the Bible mankind experienced and continues to experience as real situations of salvation or damnation." ${ }^{22}$ It is precisely this "existential," and not "scholastic" approach to the problem of the relationship between grace and freedom that was the first one of the most crucial reasons why Augustine's views were readdressed. The other one, which was no less

20 Cf. V. Grossi, L. Ladaria, P. Lécrivain, B. Sesboüé, Historia dogmatów, op. cit., pp. 262-264.

21 Cf. V. Grossi, L. Ladaria, P. Lécrivain, B. Sesboüé, Historia dogmatów, op. cit., p. 264.

22 G. Müller, Dogmatyka katolicka, op. cit., pp. 797-798. 
crucial, was the belief that despite the errors he made, Augustine was quite correct in conveying all that the Christian Revelation had to say about grace and freedom.

Undoubtedly, Augustine's line of reasoning was pursued in the Decree on Justification issued by the Council of Trent, as his views gave rise to synodal disputes over the problem of justification. The pronouncements contained in the Decree emphasize the selfless character of God's gift. Even though the Decree was polemical, it presented the teaching, which was "balanced and generally calm, on the doctrine of justification by grace - a central chapter in the Catholic dogmatics." 23

Given the discussion between Tischner and Kołakowski, which is at issue here, we should lend more weight to the next major stage in this controversy, namely the controversy over Jansenism. Cornelius Jansen, whose Latinized name - Jansenius - was used to coin the name of the controversy, serves in the history of thought as the main point of reference as regards Pascal's thought, and as the symbol of dispute with Jesuit theologians. ${ }^{24}$ The above-mentioned treatise On Rebuke and Grace by Augustine is the key to Jansen's doctrine. Of particular significance is the fact that Jansen reinterprets the original Augustinian categories by slightly shifting points of focus around. He introduces the distinction between "sufficient grace" and "efficacious grace." The Augustinian concept of adiutorium sine qua non becomes "sufficient grace" in Jansen. Christ's grace - adiutorium quo in Augustine - becomes "efficacious grace" in Jansen.

Jansenius shifted the accents in response to the changes in the theology of grace that had already been taking place in the Middle Ages.

23 Cf. V. Grossi, L. Ladaria, P. Lécrivain, B. Sesboüé, Historia dogmatów, op. cit., pp. 288, 306-307.

${ }^{24}$ Kołakowski summed up this dispute as follows: "The striking thing about Pascal's dispute with the Jesuits is the paradoxical character of both the positions. The crux of the dispute is the same as in all ideological disputes throughout the history of Christianity - the relationship between the finite world of experience and the supernatural world, and therefore the way in which earthly life is included in the perspective of infinity, and the way it is separated from it, as well as the character of this fine borderline on which our world comes into contact with the unknown reality unfettered by space or time" (L. Kołakowski, Banał Pascala [Pascal's Banality], in: L. Kołakowski, Chrześcijaństwo [Christianity], wstęp, wybór i opracowanie H. Czyżewski, Kraków 2019, pp. 237-238). 
The rationale behind these changes was that Augustine's position was turned into a discussion of the inner nature of grace. Jansenius takes this trend even further. He inquires into the grounds on which grace is "sufficient" or "efficacious." He also inquires about what, in the face of grace thus construed, remains in the realm of human freedom. One might say that Jansenius reads Augustine in the spirit of the opposition between grace and freedom. Such was also the interpretation of Augustine's views by Luther and Calvin. In accordance with such an interpretation grace is a force irresistible to human freedom. ${ }^{25}$

Jansenism is a highly modified form of Augustianism. It is a far-reaching over-interpretation of Saint Augustine's thought - one resulting from medieval shifts. Augustine showed above all the interaction between grace and freedom. He did this by defining grace as aid (adiutorium, auxilium) for free will, and he avoided presenting it as a competitor for human freedom. The shifts made by Jansenius made it impossible to approach the relationship between grace and freedom in a manner doing justice to the original Augustinian approach to the issue.

\section{Semi-Pelagianism according to Kołakowski}

Kołakowski interprets the 17th-century Jansenism not only as an attempt at dealing with the irresolvable mysteries of Christianity, but also as a reactionary model of Christian faith and a desperate attempt at stav-

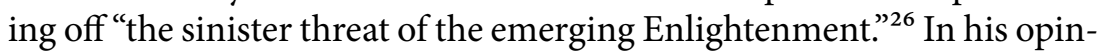
ion, human thought moves and needs to move between two extremes,

25 Cf. V. Grossi, L. Ladaria, P. Lécrivain, B. Sesboüé, Historia dogmatów, op. cit., p. 258. Clement XI's bull Unigenitus, which was a response to Jansenism, condemned, inter alia, the following theses: "When God wishes to save a soul, at whatever time and at what ever place, the undoubted effect follows the Will of God. [...] When God wishes to save a soul and touches it with the interior hand of His grace, no human will resists Him" (as cited in Breviarium fidei, op. cit., p. 339).

${ }^{26}$ Kołakowski defines Pascal's thought, which is rooted in Jansenism, as "anti-Enlightenment." In his opinion, in Pascal "the rift between the Christian - in its pejorative sense - «world" and the realm of faith cannot be healed; these two realities have no point of contact in the intellectual, moral or ontological sense [...]" (L. Kołakowski, Zaproszenie od Pana Boga na biesiadę. Dialog XVII-wieczny [An Invitation from God to a Feast. Dialogue in the 17th Century], in: L. Kołakowski, Czy Pan Bóg 
i.e. Pelagianism (in the period he describes a particularly significant version of Pelagianism was Molinism - a Jesuit theology severely criticized by Pascal) and Augustianism (Kołakowski believes Jansenism to be its new variety). Kołakowski expresses the inevitability of moving between the two extremes in thinking about the relationship between grace and freedom with a quotation from P. Bayle: "So miserable is human destiny that the lights which deliver man from one evil throw him into another." ${ }^{27}$

The point at issue between these two positions can be encapsulated in a question whether we contribute to our redemption, and if so, then how we do that. Kołakowski believes that by condemning Jansenism the Church condemned Saint Augustine himself, even though it did not admit that openly. ${ }^{28}$ Kołakowski argues that there were weighty reasons why the Church had to get rid of some part of the legacy of Saint Augustine, if the Church wanted to preserve its power. In his opinion the Church, as it was formulating its teachings, virtually adopted the Jesuit (or semi-Pelagian, as Kołakowski claims) doctrine on the key issues concerned with original sin, grace and predestination. In his view, if the Church had at that time adopted the Augustinian-Jansenist theology as the basis for its educational activity, it "would have embarked on the road to self-destruction." ${ }^{29}$

In Kołakowski's opinion, the Augustinian-Jansenist theology contains the following theses:

1) we're hopelessly corrupt, and so we are only capable of evil;

2) grace is indispensable, and when it is granted, its action is unfailing;

3) grace is both a necessary and sufficient condition for good works;

4) Jesus Christ could not have died for all mankind - He knew who would be damned, and who would be redeemed - He did not spill His blood in vain. ${ }^{30}$

jest szczęśliwy i inne pytania [Is God Happy and Other Questions], wybór i układ Z. Mentzel, Kraków 2009 , p. 24).

27 L. Kołakowski, Bóg nam nic nie jest dłużny, op. cit., p. 10.

28 See L. Kołakowski, Bóg nam nic nie jest dłużny, op. cit., p. 12.

29 See L. Kołakowski, Bóg nam nic nie jest dłużny, op. cit., pp. 44-45.

30 See L. Kołakowski, Bóg nam nic nie jest dtużny, op. cit., pp. 46-47. 
By juxtaposing these theses with Augustine's views, which are discussed above, we can see that only the latter one can be found in the writings by the bishop of Hippo. Kołakowski erroneously identifies Augustine's theses with Jansenius' theses. All the rest, even if it is Jansenist, is not Augustinian. Contrary to what Kołakowski claims, by condemning Jansenism, the Church did not condemn Augustine's views, but only one of the versions of Augustinianism, one far removed from what Augustine himself preached.

The rationale behind this rejection - as Kołakowski rightly points out - was the belief that it is difficult to teach morality, if the salvation of man has nothing to do with his conduct. In a case like this, the idea of moral responsibility becomes meaningless. In Kołakowski's opinion the thesis about "double predestination" which is contained in the Jansenist doctrine is a theological expression of the belief held by the Church, whereby it is God's invincible army - the belief that "we, as Christians, are under grace. This means that we must trust our Father and not bargain with him." Kołakowski contends that that was "a theological sword in the hands of a militant Church." If Pelagius' views had prevailed, the Church would turn into a spiritual aristocracy incapable of fulfilling its mission. ${ }^{31}$

Kołakowski suggests that up to the times of the Counter-Reformation, the Augustinian interpretation of original sin, grace and predestination was predominant in the official, authoritative teachings of the Church. ${ }^{32}$ In his opinion, the Church did not reject these theological elements, because the doctrine of predestination was well suited to the mentality of people who sought moral security, and who were anxious to believe that they were God's elect. Even if libido sciendi was gradually

31 Cf. L. Kołakowski, Bóg nam nic nie jest dłużny, op. cit., p. 49.

32 One can hardly agree with such a proposition. As I have demonstrated above, Augustine discussed the issues concerned with the relationship between free will and grace, as well as the problem of predestination and human freedom. He did not, however, impose any solutions. That which Kołakowski calls the Augustinian interpretation of original sin is an object of neither Church's faith nor its dogmatic pronouncements. And by no means did the Church enforce acceptance of such theses for that matter. 
rising to the surface, the Church postponed the decision to reject $\mathrm{Au}$ gustinianism for a long time. According to Kołakowski such a theology worked not only in the early days of the Church, when it could regard itself as a persecuted minority, but also in its heyday. The belief that people are by nature evil and corrupt was to serve as justification for the Church machinery of coercion, the existence and use of which was to be justified by the desire to give people their salvation and to safeguard them against the destructive influence of those who were inclined to offend God. In Kołakowski's view there is some kind of "pre-established harmony" between the Augustinian theology and more or less theocratic claims made by the Church. ${ }^{33}$

As one takes into account the above-presented course of the discussion about grace and freedom that has taken place in the history of theology, one might conclude that Kołakowski assigns too great a role to Augustine himself as well as to his views, which he anyway interprets according to a highly ideologized formula. Undoubtedly, the image of the history of the Church that sticks to Manichaeism-suffused division into "the good" and "the evil," and canonizes this division in Augustine, is very evocative. However, it can hardly be considered to be true.

Still, Kołakowski is right in claiming that in the times in question the Church had to stand up to new questions willy-nilly. The most crucial ones of these were concerned with the question whether human nature is a rebel that needs to be crushed, or perhaps it is something that is only slightly flawed, and so can be tamed, ennobled and mended. The consequence of this question was another one concerned with appropriate methods of education. This question was about which one is a better method of education: violence or patient formal education that was the crux of the dispute between Jansenists and adherents of the Jesuit theology. According to Kołakowski, the stake in the dispute was the adaptability of Christianity to the new civilization that had been secretly developing and maturing for several centuries. For quite some time now attempts had been made to resolve these dilemmas. These

${ }^{33}$ Cf. L. Kołakowski, Bóg nam nic nie jest dłużny, op. cit., pp. 62-63. 
attempts included - as Kołakowski remarks - texts by Erasmus of Rotterdam. However, what Erasmus proposed was not theology par excellence. ${ }^{34}$ Kołakowski believes that theology requires unambiguous "yes" or "no" answers to the key questions, i.e.:

- does our free choice help our salvation?

- does it lie within our power to cooperate with grace?

Kołakowski claims that if we answer to the above questions in the affirmative, then our position is that salvation is up to our efforts. Consequently, we consider that we need to supplement God's grace with our own action, and so grace is necessary, but insufficient. In Kołakowski's opinion, the result is the semi-Pelagian heresy. The negative answer leads to the thesis that everything - all our action - comes from God. That is the answer that in Kołakowski's opinion was provided by Augustine, Calvin and, of course, Jansenius. As I have written before, such an answer can be ascribed to the latter two, but not to Augustine.

In Kołakowski's opinion, this dilemma, which involves far-reaching implications, has never been resolved, despite enormous efforts made by Catholic theologians. In the times that Kołakowski describes, an unambiguous "yes" or "no" was, in his opinion, required - it was necessary to answer the following question: do you stand for Athens or Jerusalem, for God or man? ${ }^{35}$ Kołakowski writes: "The point of the controversy over grace appeared to be absolutely clear in the Christian terms, both educational and political ones. Advocates of absolute predestination wanted to arouse the spirit of true piety as the opposite of easy deeds." ${ }^{36}$

${ }^{34}$ Cf. L. Kołakowski, Bóg nam nic nie jest dłużny, op. cit., pp. 65-66. Elsewhere Kołakowski writes about Erasmus' views as follows: “[...] Erasmus' moral philosophy is apparently, in the 16th century, «the third force» in Christendom. It opposes the Lutheran hope of spontaneous benefits of the organisational rift, and opposes the Lutheran contempt for all efforts made by «natural» man. At the same time, he promotes the model of Christian life which, contrary to the Church mores, does not multiply values thanks to ceremonies, rites, scholastic erudition, ritual «deeds,» but becomes almost entirely reduced to moral practice, where both a good intention and a good deed are always construed as necessary conditions" (L. Kołakowski, Erazm i jego Bóg [Erasmus and His God], in: L. Kołakowski, Chrześcijaństwo, op. cit., p. 35).

35 Cf. L. Kołakowski, Bóg nam nic nie jest dłużny, op. cit., p. 67.

36 L. Kołakowski, Bóg nam nic nie jest dłużny, op. cit., p. 69. 
According to Kołakowski, the 17th-century dispute between the Jansenists and Molinists only revealed that which had been a fact for several decades: namely the fact that rejection of Augustinianism must inevitably lead to semi-Pelagianism. One more solution could have been applied, even though in Kołakowski's opinion there was no way anyone would regard it as an honest one. The solution would have been to talk about these issues in unclear and vague language. If accurate language is spoken - which in Kołakowski's opinion should be the case in theology - then the condemnation of the Calvinistic views must inevitably be connected with being in favour of actual semi-Pelagianism, even if one avoids mentioning the name. Condemning semi-Pelagianism, and by extension choosing the path first marked by Augustine, turns a theologian into a crypto-Calvinist, even if he declares his rejection of this view. ${ }^{37}$

According to Kołakowski, over the centuries the Church saved itself by using ambiguous theological language, but the Jansenists forced the Church to make the choice. ${ }^{38}$ The rejection of Jansenism resulted in "de-Augustinianization" of the Church. Kołakowski believes that the main reason why such a move was made was because the Catholic theologians came to understand that it was no longer possible to impose discipline and earnestness on the upper classes of society. Kołakowski argues that the Augustinian austerity was not suitable for ballrooms and theatre-goers. ${ }^{39}$ Many libertarians and sceptics lived in the times that witnessed the 17th-century controversy over the relationship between freedom and grace. Also deists engaged in social activity; they based their views on science and questioned the truths contained in the Bible. ${ }^{40}$ The strategy of the Jesuit theologians, which consisted in shifting to semi-Pelagian positions, was in Kołakowski's opinion an attempt

37 Cf. L. Kołakowski, Bóg nam nic nie jest dłużny, op. cit., p. 75.

38 Cf. L. Kołakowski, Bóg nam nic nie jest dłużny, op. cit., pp. 75-76.

39 This statement too can hardly be recognized as convincing. In the 17th century Augustine enjoyed great popularity among both Catholics and Protestants.

40 Kołakowski's belief that deists based their views on the sciences emerging in the 17 th and 18 th centuries is at variance with the factual state of affairs. In the views held by such thinkers as Collins, 
at finding in the Church a place for people like these. These theologians continues Kołakowski - did not want to throw such people out of the Church, thereby condemning them to eternal damnation. And so to save them they adjusted theology to them. What is more, by adopting the semi-Pelagian solution, the Church demonstrated great flexibility that allowed it to survive in the society that had undergone a dramatic attitudinal change. By using the art of differentiation, which was passed down in the history of the Church, it was possible to preach, in line with the developing humanism, theses about nature being good, and so we need to solidarize with it, accompany it and improve it, but without resorting to force or coercion. ${ }^{41}$

Kołakowski attacks yet another vital element in the Jansenist theology, which for him is represented by Pascal, i.e. the Christocentrism of this theology. In his view, making references to the figure and work of Jesus Christ was an act of mental desperation resulting from the thesis about the unknowability of God, According to Kołakowski, emphasizing the placement of the problem concerned with the relationship between grace and freedom in the Christological context was merely an escape and by no means a viable solution, because it resulted from a radical

Toland or Tindal there are no references to science, but rather criticism of revealed religion, as well as natural theology, teachings on natural reason and common sense.

${ }^{41}$ Cf. L. Kołakowski, Bóg nam nic nie jest dłużny, op. cit., pp. 77-78, 80. Elsewhere Kołakowski explains as follows: “The Roman Church - as it desired to preserve, in its arsenal of ideological means, faith in the value of man's conduct for the sake of salvation (which lent greater effectiveness to the principle of obedience to the Church precepts), and to save the faith in the absolute omnipotence of the providence and man's impotence - encapsulated both the desires in intrinsically incoherent formulas; this incoherence came to the fore in the dispute between the Jansenists and Molinists, where both the sides referred to the same dogmas and resolutions to prove diametrically opposed theses. Noteworthily, the Jesuits represented the Church's endeavour to maintain the policy that was morally flexible enough to cater for the aristocratic and courtly clientele, for whom they provided salvation with the aid of undemanding formalities; the Jansenists - Pascal being foremost among these - presented the situation of man as a being not only bearing absolute moral responsibility for his acts, but above all being justly granted salvation or rejected on the grounds of which man could not have the slightest idea" (L. Kołakowski, Światopogląd XVII stulecia [The Worldview in the 17th Century], in: L. Kołakowski, Chrześcijaństwo, op. cit., p. 153. 
division between faith and knowledge. ${ }^{42}$ Ultimately, it appears that the only way to avoid falling into the trap of fideism, which was a result of following Augustine's thought (and which, as Kołakowski suggests, is what happened to Pascal) is to take the semi-Pelagian position. According to Kołakowski, faced with the choice between fideistically-inclined Augustinianism and semi-Pelagianism is the Church of today as well. ${ }^{43}$ The consequences of this choice are also to be found outside theology: in the domain of the thought about education and politics.

\section{Tischner}

Not only does Tischner argue against Kołakowski's theses, but he also develops the Augustinian-grounded theology of grace and freedom. For Tischner, Kołakowski is not merely a historian of philosophy who poses questions about issues that are interesting in themselves. He writes that Kołakowski takes on the role of a "master of faith." What is this role about? Tischner explains that through his reflection on Pascal's religion Kołakowski confronts the contemporary reader with the question of "what kind of faith?" - this question is not about "whether" to believe, but "how" to believe. The things that Kołakowski writes about the author of The Provincial Letters enables one to have a feel of the opposites that manifest themselves in Pascal's faith, as well as to "better understand one's own faith and unbelief." ${ }^{4}$

Tischner agrees with Kołakowski as to the fact that the background to Pascal's views is constituted by Jansenism, and the background to Jansenism is in turn constituted by Saint Augustine's views. Tischner credits the latter one with the most profound, among all the Church

42 Cf. L. Kołakowski, Bóg nam nic nie jest dłużny, op. cit., pp. 184-185. This view by Kołakowski can be seen as an effect of his ignorance of these Christological themes which are related to the question of the relationship between grace and freedom, and which are present in the thought of Saint Augustine.

${ }^{43}$ Fideism too is not a position that might be ascribed to Saint Augustine. It might, however, be found in Jansenism, i.e. in a modified, or even distorted version of Augustinianism.

44 See J. Tischner, Szukając mistrzów naszej wiary, op. cit., p. 237. 
Fathers, intuition of the advantage that evil has over mankind's forces. $\mathrm{He}$ is, however, aware that Jansenism is a radicalized teaching of Saint Augustine. He points out that the key to Jansenism is the problem of irresistible grace which is granted to man by God, and the existence of which gives rise to the problem concerned with the possibility of the existence of freedom in the human subject.

The agreement between Tischner and Kołakowski is also concerned with the fact that Pelagianism matched the mindset of people living in modern Europe. Affirmation of freedom, and scepticism as to the answer to philosophical, scientific and theological questions created favourable conditions for this old idea to flourish again. Another reason why people in those times inclined towards Pelagianism was in Tischner's opinion the fact that mankind began to succeed in fighting evil. The success was to be seen in the field of science, economy and politics. In consequence, there followed some questions about the significance of these human achievements for heaven, and about the evaluation of the actions undertaken by the protagonists of the new civilization. ${ }^{45}$

However, Tischner does not agree with Kołakowski as to the true intentions of the Jesuit theologians. In his opinion these theologians did not care so much for the adjustment of theology to the developing society, as for the theological truth about God and man. According to Tischner their desire was to find answers to the following questions:

- did Christ die for all people, or only for the elect?

- can we cherish hope as we regard man?

- can those who have not heard of Christ cherish hope? ${ }^{46}$

Another point of disagreement is Kołakowski's thesis whereby all modern utopias have Pelagian views as their background. Tischner suggests that while it is possible to agree that the Pelagian optimism may be the reason for carelessness in the approach to people, which might have disastrous consequences, and that the democratic and liberal utopias have a Pelagian background, he does not agree to treating national

${ }^{45}$ Cf. J. Tischner, Szukając mistrzów naszej wiary, op. cit., pp. 244-245.

${ }^{46}$ Cf. J. Tischner, Szukając mistrzów naszej wiary, op. cit., pp. 245-246. 
socialism and communism as inspired by Pelagianism. In his opinion these two bloodiest utopias are of Manichaean origin. ${ }^{47}$

Tischner interprets the essential meaning of the dispute between Jansenism and Molinism differently from Kołakowski. He also stresses that the controversy over grace and freedom was a controversy over power. Even though officially it was about controversy over God's power over the world, it was also about the meaning of power in general. It was the state, and above all the Church, that was supposed to adjust to the model of the Divine power. In Tischner's opinion, the era-specific "knowledge" of God and man's self-knowledge are reflected in the theory of grace. At play is here also knowledge of the nature of effect not only God's effect on the world, but also one man's effect on another man. ${ }^{48}$ Tischner believes that the background to the controversy over the relationship between grace and freedom contained the conception of power in terms of dominance. However, as he reminds the reader, it is possible to conceive of power differently - in terms of reciprocity. In both the positions - Pelagianism and Jansenism - inherent was the conviction that God dominates over the world, like the cause dominates over the effect. Even if the intention was to avoid thinking in terms of "bad fate," which is bondage to sin, one fell into the arms of "good fate," which is man's destiny to be redeemed. ${ }^{49}$ However, as Tischner observes, God revealed in the Bible does not fit in with the scholastic model of cause. He is a God who does not so much "have an effect," as chooses, speaks, reveals Himself, dies - and in all this He calls for reciprocity, for dialogue. ${ }^{50}$

The most crucial area of disagreement is the assessment made by Kolakowski, whereby in the times of the Jansenists' dispute with the Molinists the Church chose the path of semi-Pelagianism. He also does not hold with the thesis that it is possible to get away from the choice:

47 Cf. J. Tischner, Szukając mistrzów naszej wiary, op. cit., pp. 246-247.

48 Cf. J. Tischner, Podgladanie Pana Boga, op. cit., p. 252.

49 Cf. J. Tischner, Szukając mistrzów naszej wiary, op. cit., p. 258

50 Cf. J. Tischner, Szukając mistrzów naszej wiary, op. cit., pp. 247-248. 
either Augustinianism or semi-Pelagianism. In Tischner's opinion resolving this dilemma consists in renouncing the ontology of dominance.

Tischner explains that the choice of Augustinianism or semi-Pelagianism is merely about changing the "arrangement of the pawns." But the point is to abandon the "whole chessboard." 51 This abandonment is about cleansing theology of the remains of the Aristotelian tradition, and restoring the Biblical, dialogic dimension. This will enable revelation of a different vision of man, as well as a different vision of Christianity. What is contained therein? Tischner writes: "God died for all people. God wants all people to be redeemed. His basic mode of action is the Word. The Word becomes flesh and of Its own free choice dies for man. There is some Power in it. But what kind of Power? «The Power of powerlessness»? The Power of Good which «spreads by itself» and not like billiard balls." 52

In Tischner's opinion, understanding the relationship between grace and freedom, which is characteristic of the texts of the Second Vatican Council, makes it possible to usher in a new era in understanding Christianity. This is because it enables redefinition of the Church's attitude to civilisation, the state, other religions, as well as reconception of the Church's crucial tasks in the world. Thanks to this approach we can get rid of the dilemma that theology has been attempting to resolve for centuries: either grace is a limitation on freedom, or freedom is a limitation on grace. According to the new vision of the relationship between the two realities, freedom is seen as a gift from grace. Thanks to such an approach it also becomes possible to stress that freedom is an interhuman value. ${ }^{53}$ In order to speak about this in an understandable and

51 Tischner writes: "Kołakowski suggests that the Church headed in the direction of the golden mean between the extreme of Jansenism and the one of Pelagianism, in the direction of some «semi-Pelagianism.» In my opinion it is something else - it is heading in a new direction. We are renouncing the ontology of dominance. We are not into new arrangements of pawns, because there are no new arrangements any more, but we are abandoning the whole chessboard" (J. Tischner, Szukając mistrzów naszej wiary, op. cit., pp. 248-249).

52 Cf. J. Tischner, Szukając mistrzów naszej wiary, op. cit., p. 249.

53 Tischner writes: "grace opens one up to me a n ing. He who has experienced grace knows that it is good to catch fish that satisfy man's hunger, but it is even better to «catch» people - beings 
convincing manner, it is necessary, in Tischner's opinion, to give up the language of ontology, and in part even the language of transcendentalism, and instead employ the language of the philosophy of dialogue, with the philosophy of good and the philosophy of value contained therein. ${ }^{54}$

As he formulates his own conception of freedom, Tischner follows Augustine's path of that which in the Augustinian theology is best. However, it is clearly visible - as Tischner tries to more lucidly express that which is contained in the Church teaching on this issue - that the whole Church follows Augustine's path, extracting from his thought on grace and freedom that which is accurate and most precious, and removing that which is erroneous. It is also clearly visible that although Tischner refers to the approach to the relationship between grace and freedom adopted by the Second Vatican Council as "new," this "novelty" as usual in the history of Christianity - is a return to the well-interpreted tradition cleansed of erroneous approaches.

\section{Resolution of the controversy}

Now that we have discussed Kołakowski's and Tischner's views, let us try and show the possibility of reconciling the two perspectives, and formulate postulates that result from this dispute. Let us also pay attention to the consequences of this dispute in the sphere of philosophy of education and the philosophy of politics.

Kołakowski is wrong in claiming that up to the modern period the Church's thinking was purely Augustinian - which is to say that it unquestioningly followed Saint Augustine - and then as a result of the change in the cultural situation, it gave up Augustinianism for the sake

that «shall not live on bread alone, but on every word that comes from the mouth of God». Grace lifts man onto a new «level of life.» It does not destroy freedom, but enables its existence «on a new level». Thanks to freedom, which has become «a gift from grace», man can «be at home with himself.» Grace is «tempting» not only in that «it is good not to lie,» but also in that «it is great» to ch o o se to live the truth. In and through it, freedom itself becomes man's greatest «temptation» - greatest because it is most human (J. Tischner, Podgladanie Pana Boga, op. cit., p. 275).

54 Cf. J. Tischner, Podgladanie Pana Boga, op. cit., pp. 275-276. 
of semi-Pelagianism. While it is arguable that the Church's doctrine with regard to the relationship between grace and freedom was essentially $\mathrm{Au}-$ gustinian, it must be stressed that the very beginning of the controversy already saw rejection of that which was most controversial in the views held by Saint Augustine, i.e. the belief that grace is granted to some people only. The dispute between the Jansenists and Molinists too did not lead to rejection of the thought of Saint Augustine. The choice formulated by Kołakowski (either Augustinianism or semi-Pelagianism) is false, because he interprets Augustinianism in the spirit of Jansenism. The Church chose and continues to chooses a third solution, i.e. it accepts Augustinianism which is devoid of errors related to predestinarianism, and which best resolves the relationship between grace and freedom.

However, one cannot but agree with Kołakowski when he says that the Church's practice did not often go hand in hand with dogmatic pronouncements. He rightly stresses that despite appropriately formulated pronouncements, in practice the Church was semi-Pelagian. This claim appears to be true not only with regard to the Church in the previous centuries, but it remains relevant today as well. There is no shortage of examples - sermons preached and pastoral programs formulated today.

Tischner too is aware of this danger. He believes, however, that we are not condemned to waver between the extreme of pessimistic Augustinianism and the one of naively optimistic Pelagianism. Nor does he regard semi-Pelagianism as the desirable golden mean between the two extremes. The whole problem appears to lie in that which the Church has been grappling with since its beginning, namely the difficulty in reconciling orthodoxy and orthopraxy. It is not enough for the Church to be free from ill-construed Augustinianism or semi-Pelagianism at the doctrinal level. The point is that it de facto should not be semi-Pelagian or Jansenist at the practical level. If Christianity still lies ahead ${ }^{55}$ - which

55 Tischner wrote: "I am convinced that Christianity - the Gospel - lies not so much behind, but ahead of us" (J. Tischner, Wiara $w$ godzinie przełomu [Faith at the Hour of the Turning Point], in: J. Tischner, Ksiadz na manowcach, op. cit., p. 13). In this essay, which is devoted to the contemporary 
is what Tischner believed - then we still need to learn not only what to think of God, but also how to translate this thinking into practice (above all in its pastoral dimension).

Kołakowski is right in his assessment whereby theology of creation was the crucial element in the controversy in the 17th century. He writes: "The controversy was over the spiritual foundations of Christianity; it can be viewed as re-updating - in a new cultural situation - of the never-ending conflict that lies in the roots of Christianity, in the very ambiguity of the idea of creation." ${ }^{56}$ In his opinion the optimistic approach to nature places us on the Molinist side, but emphasizing the chasm between God and creation puts us in the Jansenist position. Kołakowski argues that this conflict arises out of the idea of "the infinite ruler who calls into existence finite things." ${ }^{57}$

As Tischner points out, the error in such thinking is caused by conceiving of creation in abstracto. But in order to conceive of it correctly, one needs to view it in the context of the history of salvation. It is precisely for this reason that Christology is not a redundant addition, nor an escape from a theoretically difficult situation, but the essence of Christian thinking about the relationship between grace and freedom. This is because one cannot speak about the drama, which is partly constituted by the relationship between grace and freedom, without a reference to incarnation and life in the Holy Spirit. As Tischner stresses, one can properly conceive of freedom only "within the horizon of incarnation." 58 And it is precisely within this horizon that one should view the problem of grace.

These two crucial postulates concerned with theological issues, as well as with their theological and pastoral consequences already show

situation of Christianity in Poland, Tischner also cites Kołakowski's views contained in his book Świadomość religijna i więź kościelna. Studia nad chrześcijaństwem bezwyznaniowym XVII wieku [Religious Awareness and Ecclesial Bond. A Study of Non-denominational Christianity in the 17th Century], Warszawa 1997.

56 L. Kołakowski, Bóg nam nic nie jest dłużny, op. cit., p. 88.

57 L. Kołakowski, Bóg nam nic nie jest dłużny, op. cit., p. 89.

58 Cf. J. Tischner, Spór o istnienie człowieka, op. cit., pp. 384-392. 
how much one can learn by carefully following Tischner's dispute with Kołakowski. However, the positions taken in the controversy over the relationship between grace and freedom have diverse consequences, not only in the realm of religious thinking, but also in the spheres of the theory of education and of politics. As I pointed out at the beginning, this is the reason why this issue cannot be treated as a merely theological question, but it should be approached as a question with an inherent philosophical layer.

One might imply that Pelagianism and Augustinianism bring most varied images which best capture that which is the essence of each of the positions. Pelagianism evokes an image of an adult man who is capable of engaging in a spiritual struggle and achieving victory. According to this image God is an educator of man, and provides him with necessary aid in the form of good advice and support. The Jansenist version of Augustinianism evokes an image of a little, frightened child who needs help and snuggles in God's arms. In addition, semi-Pelagianism, which is supposed to be a compromise solution in relation to the other two, evokes an image of a young man who can already fight and be faithful, but needs more help and support than an adult person.

Each one of these images has its consequences in the dimension of thinking about education and politics. If the image of a self-sufficient adult person who only needs good advice is true, then education based on discipline is unacceptable. No kind of coercion is acceptable either, in the dimension of thinking about political life. But if this image is untrue, it might turn out that education without discipline, and politics based on excessive trust in human maturity may lead to the emergence of society of barbarians - people who lack discernment as to basic values, and who are self-interested.

The image of a little, helpless child - if it is true - gives rise to the postulate of far-reaching interference in the process of education, as well as far-reaching activity engaged in by the Church or the state aiming to establish order and realize values. If, however, this image is not true, then it may turn out that by employing it we will give rise to the emergence of society composed of people incapable of independent thought 
and assumption of responsibility. The consequence to be observed in the sphere of political life will be consent to church or state terror.

The image of a young man who can fight and be faithful, but who still needs help - if it is true - will give rise to education focused on the needs about which the educator is informed by educatees, moderate interventionism being the effect in the sphere of politics. If, however, it is not true, it may turn out that excessive trust placed in educatees will result in a sense of deep confusion, because it will result in a type of education construed as an experiment. In the sphere of political life it might be difficult to delineate boundaries for acceptable interventions, and find justifications for them.

As we follow Tischner's line of thought, one might say that time has come to revive yet another image, which is permanently present in the biblical thought, although as yet it is not understood or internalized enough. This image is an image of a romantic relationship. A relationship like this makes it possible to break free from fear that is connected with approaching the problem in Augustinian terms, as well as to put aside the image of man who acts "single-handedly", in a sense "outside of" God, or "in defiance of" God. This image too has some consequences for education and politics.

Internalization of this image can contribute to a radical change in our thinking about God and man. The point is to mature enough to embrace this old concept, to understand it and start implementing it. If we succeed in assimilating it, if we mature enough to handle it, then both education and politics will be different. As regards the former, the key might lie in revelation of values the realization of which is supposed to be not so much an educatee's duty, but his most cherished desire. Noteworthily, the revelation of values is not concerned with coercion, but with releasing freedom. As Tischner observes, the greater a value, the greater freedom. ${ }^{59}$ With regard to politics, the key is the concept of "participa-

59 Cf. J. Tischner, Wolność w blasku prawdy [Freedom in the Blaze of the Truth], in: J. Tischner, W krainie schorowanej wyobraźni [In the Land of Diseased Imagination], Kraków 2013, p. 169. 
tion," ${ }^{60}$ which not only excludes coercion, but also makes it redundant. If an individual and a community (be that Church or the state) do not act in opposition to one another, but on account of the same values, then there is no necessity for intervention.

\section{Conclusion}

Even though it appears to be only concerned with theoretically most advanced theological themes, Tischner's dispute with Kołakowski has some relevance that significantly goes beyond theology. Proper understanding of the history of the dispute proves to be of relevance for its resolution. Only when we properly understand the meaning of the solutions at play can we legitimately criticize them, as well as develop our own position.

However, the most important thing about this dispute is that it has its continuation in our times. It turns out that there is much more than meets the eye to the debates about the intricacies of the 17th-century controversy between the Jansenists and Molinists, as well as the precise differentiation between "Pelagianism" and "semi-Pelagianism," even though, as Tischner observes, these debates are an excellent mental exercise." ${ }^{61}$ This controversy is about us, who feel like we are pulled by two forces. In them we can see our own inner split. ${ }^{62}$

And so it is worthwhile taking a closer look at Augustine's dispute with Pelagius, or Pascal and his Jansenist companion's dispute with Jesuit theologians. It is all the more worthwhile taking a closer look at Tischner's dispute with Kołakowski. Each one of us must willy-nilly take part in these disputes and resolve them on our own. The resolution

Or with another formulation: "The greater a value, the greater the freedom to acknowledge it" (J. Tischner, Myślenie według wartości [Thinking in Values], “Znak” (1978) nr 7-8, pp. 960-961.

${ }^{60}$ As Tischner points out, the connection between grace and participation occurs, because "grace initiates us into participation" (J. Tischner, J. Żakowski, Tischner czyta Katechizm [Tischner Reads the Catechism], Kraków 2000, p. 128).

${ }^{61}$ Cf. J. Tischner, Podgladanie Pana Boga, op. cit., p. 252.

${ }^{62}$ Cf. J. Tischner, Szukają mistrzów naszej wiary, op. cit., p. 247. 
of these disputes will have an effect on what we think about proper ways to educate the next generations and about politics. This is already enough to show how important these disputes are. These disputes become even more significant when we realize that their resolution will have an effect not only on our earthly fate, but on sour eternal fate as well.

\section{Bibliography}

Augustyn św., Łaska a wolna wola [On Grace and Free Will], in: Augustyn, Łaska, wiara, przeznaczenie [Grace, Faith, Destiny], tłum. E. Eborowicz, Poznań-WarszawaLublin 1970, pp. 51-148.

Augustyn św., Nagana i łaska [On Rebuke and Grace], in: Augustyn, Łaska, wiara, przeznaczenie, tłum. E. Eborowicz, Poznań-Warszawa-Lublin 1970, pp. 149-205.

Bouyer L., Duch Święty Pocieszyciel [The Holy Spirit the Comforter], tłum. A. Liduchowska, Kraków 1998.

Grossi V., Ladaria L., Lécrivain P., Sesboüé B., Historia dogmatów [History of Dogmas], t. 2: Człowiek i jego zbawienie [Man and His Salvation], tłum. P. Rak, Kraków 2001.

Kijewska A., Augustyńskie dziedzictwo [The Augustinian Heritage], in: Przewodnik po filozofii średniowiecznej. Od św. Augustyna do Joachima z Fiore [A Companion to Medieval Philosophy. From Saint Augustine to Joachim of Fiore], red. A. Kijewska, Kraków 2012, pp. 17-41.

Kołakowski L., Banał Pascala [Pascal's Banal], in: L. Kołakowski, Chrześsijaństwo [Christianity], wstęp, wybór i opracowanie H. Czyżewski, Kraków 2019, pp. 236-244. Kołakowski L., Bóg nam nic nie jest dłużny. Krótka uwaga o religii Pascala i o duchu jansenizmu [God Owes Us Nothing: A Brief Remark on Pascal's Religion and on the Spirit of Jansenism], tłum. I. Kania, Kraków 1994.

Kołakowski L., Erazm i jego Bóg [Erasmus and His God], in: L. Kołakowski, Chrześcijaństwo [Christianity], wstęp, wybór i opracowanie H. Czyżewski, Kraków 2019, pp. 29-39. Kołakowski L., Świadomość religijna i więź kościelna. Studia nad chrześcijaństwem bezwyznaniowym XVII wieku [Religious Awareness and Ecclesial Bond. A Study of Nondenominational Christianity in the 17th Century], Warszawa 1997. 
Kołakowski, Światopogląd XVII stulecia [The Worldview in the 17th Century], in: L. Kołakowski, Chrześcijaństwo [Christianity], wstęp, wybór i opracowanie H. Czyżewski, Kraków 2019, pp. 142-166.

Kołakowski L., Zaproszenie od Pana Boga na biesiadę. Dialog XVII-wieczny [An Invitation from God to a Feast. Dialogue in the 17th Century], in: L. Kołakowski, Czy Pan Bóg jest szczęśliwy i inne pytania [Is God Happy and Other Questions], wybór i układ Z. Mentzel, Kraków 2009, pp. 20-24.

Müller G., Dogmatyka katolicka [Catholic Dogmatics], tłum. W. Szymona, Kraków 2015. Oko D., Łaska i wolność. Łaska w Biblii, nauczaniu Kościoła i teologii wspótczesnej [Grace and Freedom. Grace in the Bible, the Catholic Church Teachings and Contemporary Theology], Kraków 1997.

Tischner J., Myślenie według wartości [Thinking in Values], “Znak” (1978) nr 7-8, pp. 957-970.

Tischner J., Podgladanie Pana Boga [Stealthily Watching God], in: J. Tischner, Ksiadz na manowcach [A Priest in the Wilderness], Kraków 1999, pp. 251-276.

Tischner J., Szukając mistrzów naszej wiary [In Search of the Masters of Our Faith], in: J. Tischner, Ksiądz na manowcach [A Priest in the Wilderness], Kraków 1999, pp. 236-250.

Tischner J., Spór o istnienie człowieka [A Controversy over the Existence of Man], Kraków 2011.

Tischner J., Wiara $w$ godzinie przetomu [Faith at the Hour of the Turning Point], in:

J. Tischner, Ksiądz na manowcach [A Priest in the Wilderness], Kraków 1999, pp. 11-29.

Tischner J, Wolność $w$ blasku prawdy [Freedom in the Blaze of the Truth], in: J. Tischner, W krainie schorowanej wyobraźni [In the Land of Diseased Imagination], Kraków 2013, pp. 159-173.

Tischner J., Zarys filozofii człowieka dla duszpasterzy i artystów [An Outline of the Philosophy of Man for Priests and Artists], in: J. Tischner, Myślenie w żywiole pięk$n a$ [Thinking in the Element of Beauty], Kraków 2013, pp. 139-336.

Tischner J., Żakowski J., Tischner czyta Katechizm [Tischner Reads the Catechism], Kraków 2000. 


\section{Abstract}

\section{Tischner's dispute with Kołakowski over grace and freedom}

The present text addresses one of the stages of the controversy over grace and freedom originated by Pelagius and Saint Augustine. The protagonists of this stage are Leszek Kołakowski and Józef Tischner. As he was reconstructing the 17th-century debates between Jansenists and Molinists, Kołakowski posed a question about the relevance in: of this controversy for the contemporary times. Tischner, as he was critical of Kołakowski's views, put forward his own solution to the problem of grace and freedom, which was in line with the thought of Saint Augustine. In the present text I place Tischner's dispute with Kołakowski against the backdrop of earlier stages of the controversy, and I discuss the views held by both the thinkers. I also attempt to resolve this dispute and point to its significance for the philosophy of education and the philosophy of politics.

\section{Keywords}

Józef Tischner, Leszek Kołakowski, grace, freedom, Augustinianism, Pelagianism, semi-Pelagianism 